\title{
A View from Within: \\ Exploring the Psychology of Responsible Leadership
}

\author{
Cécile Rozuel and Tarja Ketola
}

\author{
Contact: \\ Dr. Cécile Rozuel \\ Institute for Socio-Management \\ Stirling Management School \\ University of Stirling \\ Stirling FK9 4LA, UK \\ Email: cecile.rozuel@stir.ac.uk
}

***Published in 2012 in the Journal of Management Development, 31(5), pp.444-448***

\begin{abstract}
Purpose - This paper aims to review the links between ethics, leadership and psychology, and to introduce the papers for the special issue of the Journal of Management Development. Design/methodology/approach - The paper provides a conceptual review of issues attached to research in the field of responsible leadership psychology.

Findings - Individual organisational members affect and are affected by the organisation's collective psyche, and all are potential leaders; therefore, all should care about their 'inner life' and reflect on the interrelationships between their ethical responsibility, their psychological world, and their interaction with others.

Originality/value - Self-enquiry and understanding the unconscious influences on egoconsciousness are essential for nurturing ethical awareness and responsible action as leaders, followers and more generally as organisational agents.
\end{abstract}

Paper type: General review

Keywords: Responsibility, Leadership, Psychology, Ethics 
Although the theme of this special issue, 'Responsible Leadership Psychology', may seem unusual for a management journal, the fields of psychology, ethics and leadership intersect at some fundamental levels to inform management practice. The act of leading demands a deeper understanding of interpersonal relations - which often itself demands a thorough understanding of intrapersonal relations (Pienaar, 2009) - as well as an awareness of the weblike influence of one's actions onto a wide range of other actors. According to Hodgson and Binney (2007, p. 35), leaders and managers' roles and expectations differ from those of professionals in so far as, amongst other things, they tend to mix "gut feel" with factual evidence, be flexible rather than stiffly obey standards, be part of and responsible for a group as well as themselves, and show some degree of consideration for people's emotions. This brief list already demonstrates the psychological dimension of leadership behaviour and the ethical tone of leaders' actions. This paper offers a brief overview of research at the intersections. Indeed, the respective areas of psychology, ethics and leadership, once combined, provide a range of research themes which have been explored by scholars and practitioners to various degrees. We do not argue that the axes discussed below are mutually independent; in fact, there is much overlap because of the very nature of leadership.

From the viewpoint of leadership scholarship, we can distinguish research whose purpose is primarily psychological with ethical issues being secondary, from research whose purpose is primarily ethical with some psychological implications. The first research axis is mainly oriented towards generating practical knowledge on how leaders can use psychological techniques or concepts to better understand and influence organisational life; the ethical implications lie in the initial intent and process of the psychological practices, i.e. manipulation of the collective or genuine care for others' conscious responses (see for instance Kets de Vries, 2006). Ethical caution was particularly important when the dominant leadership model was transactional; as new forms of leadership seem to have emerged, such as transformational, charismatic or servant leadership, it is often assumed that 'true' leaders are aware of their ethical responsibilities towards others (e.g. Bass, 1990; 1999). In light of yet further corporate collapses over the past year, such confidence may be misplaced. On the other hand, some leadership scholars focus on the ethical responsibility attached to the role of leader and the dynamic leader-follower; the content of their analysis, in turn, tends to draw upon some psychological concepts such as self, projection and transference (e.g. Sinclair, 2007). The initial intent here is to increase moral awareness of leadership practice, in contrast with the more instrumental intent of the alternative research axis where effectiveness may supersede ethics.

Psychologists - either organisational psychologists or psycho-analysts - have also contributed to the field. Within the applied psychology scholarship, one axis favours leadership as a focus of enquiry, whilst the other concerns itself with ethics within the context of leadership. Manfred Kets de Vries's work (e.g. Kets de Vries and Miller, 1986; Kets de Vries and Balazs, 1998; Kets de Vries, 2006; Kets de Vries, et al., 2007) illustrates the first approach: although he does not per se psycho-analyse organisations and organisational members, he uses psychoanalytical language and methods to reveal the dynamics at play within the organisation. Analytical psychology has provided valuable accounts of management and leadership development through individuation work or personality typology (e.g. Figler and Hanlon, 2008; Brown and Reilly, 2009). With this knowledge, it is assumed that individuals will be better equipped to avoid ethical traps and contribute to healthier organisations (Gabriel and Carr, 2002). Other contributors orient their psychological enquiry towards the moral issues, hidden or surfaced, of leaders and/or followers. For instance, Cobus Pienaar's review of 
possible sources of leadership ineffectiveness reads as symptoms of either an over-inflated ego sense or a weak, over-dependent ego. Pienaar (2009) ponders on the origin of a leader's "derailments" which have significant moral implications for the leader him/herself, for organisational members and for the greater organisational environment. Those leaders, he argues, "have the intellect, skills and experience to lead their companies through whatever challenges may arise, yet for some reason they are unable to do so. Something derails their best efforts - something integral to who they are, both as people and as leaders - and that operates beneath their awareness." (Pienaar, 2009, p. 136, emphasis added). Leaders thus ought to become self-aware in order to sustain the "values, goals and dreams" of the organisation (Pienaar, 2009, p. 139). Although not essentially focused on ethics, Andrew Samuels's Jungian analyses of politics and organisations also generate interesting ethical reflections in that respect (e.g. Samuels, 1990).

Finally, ethicists - primarily business ethicists - have developed models aiming at redefining leadership within moral boundaries. Although most purport to promote responsible leadership, we can distinguish contributions that rely on traditional ethics and leadership literatures from those that mix methods and concepts, for example borrowing from the field of psychology and/or spirituality (e.g. Chakraborty and Chakraborty, 2004). Thomas Maak and Nicola Pless's work on responsible leadership (Maak and Pless, 2006; 2009), or David Knights and Majella O'Leary's hybrid model for leaders based on Virtue Ethics revisited by MacIntyre and Levinas (Knights and O'Leary, 2006) adopt the former approach. The papers included in this special issue contribute, to some extent, to the latter approach. Although not all authors are business ethicists, their discussions have a firm ethical foundation. They also emphasise the essential role played by elements of the psyche - both conscious and unconscious - in the perceptions, emotions and actions of individuals. Responsible leadership, they suggest, must establish itself on a sane ground; this, in turn, requires taking a good hard look at what's inside of each individual, as well as what's inside of the organisations we create and live in. They do not claim that this is the only way towards nurturing responsible leadership; they nonetheless warrant that the psyche has a powerful ability to shake our foundations to the extent of making us lose track of our values. Affirming the self is painful but essential - a moral task in itself, according to Carl Jung (1969/1978).

The first paper of this special issue, "Generative Leadership: Responding to the Call for Responsibility", offers the viewpoint of a consulting psychologist on helping faltering managers' development. Bill Macaux first provides a valuable review of the concepts of sustainability, responsibility and accountability. Drawing parallels between literature on transformational leadership, personal responsibility and sustainability, he identifies key characteristics of a responsible management model that respects both the needs of the self and the needs of others. This, according to him, is best captured by the notion of generativity developed, notably, by psychologist Erik Erikson. The second part of the paper consists in the case analysis of 'Adam', which illustrates how "going back" (Sinclair, 2007, p. 55) helps to understand the dynamics of individual blockage and development. Bill Macaux draws upon his own experience as a coach to narrate a case of a coming-to-terms with one's issues, which are deeply rooted in childhood but pervasively influential on present behaviour. The paper reminds us that we are fundamentally shaped by our childhood relationships and experiences: the level of care received by the young self affects the experiences and performance of the adult self, so much so that a highly capable individual can collapse under the pressure of a situation recalling (unconsciously) one's deepest traumas. Bill Macaux suggests that enabling 
managers to experience this can nurture their ability to develop as generative leaders. This, in turn, benefits the whole organisation.

Tarja Ketola presents another case study, this time focusing on the organisational tensions experienced by a manager. Her paper "Losing your Self: Managerial Persona and Shadow Pressures killing Responsible Leadership" tells the story of a competent and respected researcher who, once appointed manager, struggled with the persona expectations and the shadow pressures of the organisation. Tarja Ketola offers an original analysis combining the Jungian model of psychological types with the Dharma Wheel of Buddhism. She allows readers to follow the manager's shifts of consciousness and progress alongside the Noble Eightfold Path that eventually lead to some resolution of the tensions. Tarja Ketola reminds us both of the potential we already possess but into which we often fail to tap, and of the responsibility each of us have for experiencing our lives the way we do - painfully and unconsciously, or rightfully and consciously.

In her paper "Moral Imagination and Active Imagination: Searching in the Depths of the Psyche", Cécile Rozuel also builds upon Jung's works. After introducing the ethical role of the imaginative function, she discusses in greater depth the concept of moral imagination which has gained recognition in the business ethics field in recent years. She then argues that moral imagination is not sufficient in and by itself. Rather, it must be supplemented by a careful examination of the individual's psyche in order to prevent imagination from being hijacked by complexes or shadow forces. Cécile Rozuel proposes that the Jungian activity known as active imagination can achieve this goal to some extent. She then offers an activemoral imagination model encouraging managers and leaders to look inside their psyche to sustain authenticity and integrity.

The final paper discusses the risks attached to a lack of moral imagination and, in a related manner, to mindlessness. In "Beyond the Banality of Evil: Conscience, Imagination and Responsibility", Ann Kerwin outlines Hannah Arendt's famous analysis of a dutiful bureaucratic manager and identifies the moral imperatives of autonomous moral agents. Adopting a narrative style, she reviews Arendt's core findings in Eichmann in Jerusalem and warns that the process of mindless obedience is dangerously banal in contemporary organisations and contemporary society. She then refers to later works by Arendt (whose philosophy was influenced by Immanuel Kant) to identify the essential factors that characterise individual moral responsibility: autonomous, introspective, empathic, conscious thinking as an end-in-itself living in a kingdom of ends. Ann Kerwin reminds us that the moral imperatives attached to thinking are far more demanding than what we usual wish to admit. She encourages us to "go visiting" to prevent us from falling for the lures of reassuring thoughtlessness. This - and only this - generates truly responsible leadership.

Each paper in this special issue offers a different perspective on the problems facing a leader before, during and after action. Bill Macaux's psychoanalytic coaching may not work for everybody; Tarja Ketola's Buddhist path may not suit all personality types. Similarly, practicing active imagination, as Cécile Rozuel advocates, may not evoke much response from managers or leaders endowed with a very controlling mind; the latter may find Ann Kerwin's invitation to "go visiting" more suitable, although mindfulness demands a lot of effort from the psyche. All four papers nevertheless agree on the essential qualities a responsible leader should work towards: conscious awareness of the self in its entirety, authenticity to self in one's actions, and reflective moral development through mindfulness 
and imagination. These, we suggest, make the backbone of responsible leadership. Howard (2010) agrees with Pienaar (2009, p. 139) that "the first step of any leadership development programme requires leaders to examine their greatest asset and liability, namely, themselves." We concur and further add that the self-ego dyad is inherently moral in nature: selfexploration must be done with an understanding of the ethical implications of this inner work, for there is no sustainable alternative. There lies the first and most essential responsibility of a leader.

\section{References}

Bass, B.M. (1990), "Transactional to Transformational Leadership: Learning to Share the Vision", Organizational Dynamics, Vol.18 No.3, pp.19-31.

Bass, B.M. (1998), "Two Decades of Research and Development in Transformational Leadership", European Journal of Work and Organizational Psychology, Vol.8 No.1, pp. 926.

Brown, F.W., and Reilly, M.D. (2009), "The Myers-Briggs Type Indicator and Transformational Leadership", Journal of Management Development, Vol.28 No.10, pp. 916932.

Chakraborty, S.K., and Chakraborty, D. (2004), "The Transformed Leader and Spiritual Psychology: A Few Insights", Journal of Organizational Change Management, Vol.17 No.2, pp. 194-210.

Figler, R., and Hanlon, S. (2008) "Management Development and the Unconscious From an Analytical Psychology Framework", Journal of Management Development, Vol.27 No.6, pp. 613-630.

Gabriel, Y., and Carr, A. (2002), "Organizations, Management and Psychoanalysis: An Overview", Journal of Managerial Psychology, Vol.17 No.5, pp. 348-365.

Hodgson, P., and Binney, G. (2007), "Moving Into Leadership Country", Business Strategy Review, Spring Vol., pp. 33-37.

Howard, A. (2010), “A New Global Ethic”, Journal of Management Development, Vol.29 No.5, pp. 506-517.

Jung, C. G. (1969/1978), Aion - The Collected Works of C.G. Jung Vol.9 Part II (2nd ed.), Princeton University Press, Princeton, NJ.

Kets de Vries, M.F.R. (2006), "The Spirit of Nepotism: Understanding the Tyrant Within", Human Relations, Vol.59 No.2, pp. 195-220.

Kets de Vries, M.F.R., and Balazs, K. (1998), "Beyond the Quick Fix: The Psychodynamics of Organizational Transformation and Change", European Management Journal, Vol.16 No.5, pp. 611-622. 
Kets de Vries, M.F.R., Korotov, K. and Florent-Treacy, E. (Eds.) (2007), Coach and Couch: The Psychology of Making Better Leaders, Palgrave-Macmillan, Basingstoke.

Kets de Vries, M.F.R. and Miller, D. (1986), "Personality, Culture, and Organization", The Academy of Management Review, Vol.11 No.2, pp.266-79.

Knights, D., and O'Leary, M. (2006), "Leadership, Ethics and Responsibility to the Other", Journal of Business Ethics, Vol.67 No.2, pp. 125-137.

Maak, T., and Pless, N.M. (2006), "Responsible Leadership in a Stakeholder Society - A Relational Perspective", Journal of Business Ethics, Vol.66 No.1, pp. 99-115.

Maak, T., and Pless, N.M. (2009), "Business Leaders as Citizens of the World: Advancing Humanism on a Global Scale", Journal of Business Ethics, Vol.88 No.3, pp.537-550.

Pienaar, C. (2009), "The Role of Self-deception in Leadership Ineffectiveness - A Theoretical Overview", South African Journal of Psychology, Vol.39 No.1, pp. 133-141.

Samuels, A. (1990), The Plural Psyche: Personality, Morality and the Father, Routledge, London.

Sinclair, A. (2007), Leadership for the Disillusioned, Allen \& Unwin, Crows Nest, Australia. 